\title{
Medievalista
}

Online

$30 \mid 2021$

Número 30

\section{Early Templar Administration in Provence and North-Eastern Spain}

Inícios da Administração dos Templários na Provença e no Nordeste da Espanha

\section{Alan Forey}

\section{(2) OpenEdition}

1 Journals

\section{Electronic version}

URL: https://journals.openedition.org/medievalista/4484

DOI: $10.4000 /$ medievalista.4484

ISSN: 1646-740X

\section{Publisher}

Instituto de Estudos Medievais - FCSH-UNL

\section{Electronic reference}

Alan Forey, "Early Templar Administration in Provence and North-Eastern Spain", Medievalista [Online], 30 | 2021, Online since 01 July 2021, connection on 24 July 2021. URL: http://

journals.openedition.org/medievalista/4484 ; DOI: https://doi.org/10.4000/medievalista.4484

This text was automatically generated on 24 July 2021.

\section{(c) (1) (8)}

Mediavalista está licenciado com uma Licença Creative Commons - Atribuição-NãoComercial 4.0 Internacional. 


\section{Early Templar Administration in Provence and North-Eastern Spain}

Inícios da Administração dos Templários na Provença e no Nordeste da Espanha Alan Forey

\section{EDITOR'S NOTE}

Data recepção do artigo / Received for publication: 29 de Setembro de 2020

Data aceitação do artigo / Accepted in revised form: 18 de Março de 2021

1 A very considerable proportion of the documents published by the Marquis d'Albon in his Cartulaire général de l'ordre du Temple concerns rights and properties in northeastern Spain, Provence and neighbouring regions, such as Roussillon, which did not come under Aragonese control until $1172^{1}$. It is, however, not easy to trace the early development of Templar administration in these districts in the years up to the middle of the 12th century, as charters sought to define what was passing into the Order's hands and not to describe Templar organisation. Terminology presents a further obstacle. The military orders were a new form of religious institution that was dominated by lay brothers, and the terms currently used in monastic foundations were not always applicable to them. To facilitate the dispatch of men and supplies to the Holy Land, the Templars and Hospitallers were also creating new forms of organisation to group together their establishments in a region. The Hospital did adopt the terms 'prior' and 'priory', but in many instances these orders were developing their own terminology. This happened, however, only slowly, and in the early years of the Temple and Hospital the words used to describe officials or establishments lacked precision and consistency. Furthermore, even when brothers were given a title before 1150, it was frequently not linked to a particular place or district. Some documents were, moreover, not precisely dated. The creation of houses and a province cannot therefore be examined very fully or precisely from a simple reading of this document base alone, but some tentative conclusions can be reached. 
2 Early grants in the West to the Temple were mostly made not for the purpose of founding houses in western Europe, but to provide resources for the Holy Land. A donation of property in the district of Carcassonne in 1133 was made to the Templars "ad tutelam et defensionem sancte civitatis Iherusalem et sancte Xpistianitatis Deo militantibus", and in the following year the count of Toulouse gave a privilege to the brothers who "civitatem sanctam cum habitatoribus custodiunt". The situation was, however, different in Catalonia, where attempts were quickly made to bring the Templars into the reconquista and to establish them in frontier castles. Raymond Berenguer III gave the stronghold of Granyena, which was described as "in mea marchia contra Sarracenos", and similar wording was used in grants of the castle of Barberà by the count of Urgel in 1132 and by Raymond Berenguer IV three years later ${ }^{3}$. Yet the Templars were not prepared at that time to assume military responsibilities in the Peninsula. In the charters recording the grants of Barberà the future perfect tense was used: the donations were made to the Templars "qui venerint et steterint cum armis in Graniana vel nostra marchia"; and Raymond Berenguer IV, probably in 1134, undertook to serve with the Templars for the first year of their service ${ }^{4}$, indicating that they had not then taken up arms in Spain.

The property that the Order rapidly gained did, however, have to be administered. The task could have been delegated to secular officials, but these would have needed close supervision, whereas the creation of Templar convents not only provided for the administration of property but also helped to attract further donations and recruits. The Hospital had already set a precedent by founding houses in western Europe ${ }^{5}$. In fact, the Temple quickly began to create an administrative structure by establishing bases in various locations. The word domus was most commonly used to describe these, but it is not always easy to distinguish Templar communities which can be termed convents from smaller establishments which housed merely one or two Templars. The word conventus was hardly ever used before 1150: a reference in 1147 to the convent of Novillas, near the border between Aragon and Navarre, was a rare exception ${ }^{6}$. A bequest in 1150 to the cavalleria of Corbins in Catalonia could also be interpreted to imply that a convent had been established there by that date, but this is an isolated use of the term ${ }^{7}$; and although the holding of a chapter at Arles in 1142 would suggest the existence of a Templar community there ${ }^{8}$, similar references elsewhere are lacking. Some documents do, however, allude to the construction of buildings, and this was more likely to happen when a convent was being created, as opposed to when a provision was being made for the accommodation of merely a single Templar administrator. A document of December 1138 mentions the place "in quo est jam edificatus et constructus mansus supradicte militie Iherosolimitane, qui appellatur a multis Mansio Dei" - that is, Masdéu in Roussillon'. Reference was similarly made to the time "quando domus Richarencarum (...) cepit edificari" in a charter drawn up in June of the following year, and a document dating probably from 1141 mentions this Provençal house of Richerenches, "que edificatur pro illis [Templariis]"10. Architectural studies have, in fact, shown that the early buildings at Richerenches were of considerable size ${ }^{11}$.

4 The titles given to Templars with administrative responsibilities are of only limited assistance. The terms "commander" or "preceptor", which later became the norm for describing the heads of convents, are almost entirely lacking in the opening decades of the Order's history: a reference to a preceptor at Arles in 1146 is possibly the sole 
example before $1150^{12}$. The only titles found in very early documents are bajulus and minister, without any territorial qualification. The term magister did, however, begin to come into use in the later 1130s and this may in some instances have been used to indicate the head of a convent. In a document which may belong to the year 1139, Rigald, master in Novillas, was named ${ }^{13}$. In the following year, the Templar Peter of Rovira was called master of Palau, to the north of Barcelona: in fact, he had wider authority, but the use of the term in relation to Palau may be of significance ${ }^{14}$. A charter drawn up between 1138 and 1147 mentions the master of Richerenches, and the term magister was used in documents relating to Douzens, not far from Carcassonne, in $1146-1147^{15}$.

5 Some documents also allude to groups of brothers who received a donation or purchase, suggesting that a house was inhabited by more than just one or two Templars. In some instances, no precise number is given: a charter about a property in Novillas, drawn up probably in 1135 , mentions two named Templars "et alios fratres qui ibidem erant", and the phrase "fratres de Novillas" occurs in another agreement made in $1143 / 1145^{16}$. But some documents do provide lists of brothers. Six were named in two charters, dated 1139 and 1141, which were copied into the Richerenches cartulary, and twelve brothers were listed in a document of the year 1142 which is also found in that volume ${ }^{17}$. It could, of course, be argued that some of the Templars mentioned in these sources were not necessarily resident in the places where the charters were drawn up. Yet the donation recorded in the document of 1142 was made to the house of Richerenches, to brother Hugh of Panaz and to "fratribus in ea nunc et semper degentibus", and almost all the Templars mentioned in these charters were named only in documents relating to the house of Richerenches. As later evidence indicates that the number of brothers in a convent was often small, those listed in these Richerenches charters were certainly numerous enough to constitute a convent.

Before 1150 some of these brothers held posts which became characteristic of Templar convents. A claviger is recorded in the documents of Richerenches from 1141 onwards, although this is the only house where this official is mentioned before the middle of the century ${ }^{18}$. Nicholas, described as "noster cappellanus", was named in a document listing donations to Douzens between 1134 and $1139^{19}$, and the earliest references to brother chaplains at Richereches occur in charters dated between 1136 and 1139, while a chaplain at Arles was mentioned in $1146^{20}$. Earlier, in 1136, the bishop of Vich had agreed that the chapel in the castle of Granyena should have a priest "eiusdem religionis sine proprio viventem (...) ad servicium Dei et ecclesie et sancte fratrum congregationis" ${ }^{21}$. This concession was prompted by a Templar petition, but it is not known whether a chaplain was in fact appointed at this time. The term congregatio has been taken to imply that a Templar community already existed there ${ }^{22}$, but the word could have been referring to the Order in general, and it is clear from later negotiations between the Templars and the count of Barcelona that in 1136 they still had no military role in Catalonia, while the first reference to a commander at Granyena is not found until $1181^{23}$. The number of brother chaplains in the Temple was, however, at all times small, and they were usually found in convents, rather than in lesser establishments, although there are a few exceptions ${ }^{24}$.

7 Links between laymen and the Order in some cases also suggest the existence of convents. A document in a Douzens cartulary states that in 1129, a couple gave the Temple all their property "sine ulla retinentia preter victum et vestitum." This has 
been taken to refer to a corrody, but it may mean that they merely retained enough land to provide for their livelihood: there is no specific reference to a maintenance grant by the $\operatorname{Order}^{25}$. In 1136, however, it was recorded that a Catalan benefactor was promised food and clothing, possibly at Palau ${ }^{26}$, and as early as 1132 a woman called Açalaidis gave herself "ad servicium Dei faciendum subtus obedientiam de ipso magistro [Templi] (...) sine ulla proprietate", and she later added that she was acting "propter quod Dominus meus fuit dignatus esse pauper per me, sicuti ille fuit pauper per me, sic volo esse paupercula per illum" ${ }^{27}$. She was apparently attaching herself to a Templar community which by then existed at Masdéu. Four years later Ermengol of So requested in his will that if he died in the West before going to Jerusalem "corpus suum deferri ad ipsum Mansum Dei, quem [sic] de ipsa cavalleria est, ut est factum" ${ }^{28}$. Burial at Masdéu seems by then to have become an accepted practice ${ }^{29}$. Two confraternity lists copied into the Novillas cartulary also suggest that burial at that Aragonese house was already common before the middle of the century, for these were both drawn up before $1150^{30}$. The compiling of such lists is itself a further indication of the development of Templar administration at Novillas. Thus, although it is not possible to discern exactly when convents were established, it is clear that the process had begun already in the 1130s.

8 It became the norm for Templar convents to have dependencies or granges subject to them in various places within the boundaries of a commandery, and these were administered often only by a single Templar, who was answerable to the head of the convent. The beginnings of this arrangement can be discerned in the years up to 1150 . Most Templar properties in Aragon and Navarre were under the authority of the head of Novillas, but subordinate officials became responsible for particular districts. In 1148 Rigald Viger, the master of Novillas, and "frater Gitardus qui tenebat Hambel" ${ }_{31}$ were involved in a boundary dispute, and in the following year a sale was made to Rigald Viger and the Templar Dominic "qui tenebat Boquiennic", farther down the Ebro from Novillas ${ }^{32}$. A house in Barcelona was mentioned in $1150^{33}$, but this was subordinate to the convent at Palau until the later 13th century. A late Latin version of the Gesta comitum Barchinonensium admittedly claims that nearly twenty years earlier, Raymond Berenguer III, "in fine se ipsum Deo et Hierosolymitanae militiae offerens, apud Barchinonam in domo pauperum (...) vitam finivit" ${ }^{34}$, but this is not included in earlier versions of the chronicle ${ }^{35}$, and when his will was published it was stated that the count had made it "iacens apud Barchinonam in palacio suo detentus ab egritudine qua obiit" ${ }^{36}$. These subordinate houses may have housed only a single Templar and donations were made to the head of the mother house.

The situation at Roaix, a few miles south-east of Richerenches, was, however, somewhat different. On the one hand, several gifts before 1150 were made to the house of Roaix ${ }^{37}$, and in 1148 not only was reference made to Riambald, "qui ejusdem domus curam habebat de Roaix", but also apparently to a Templar chaplain there ${ }^{38}$. Yet in 1148 and 1150 when rights there were acquired by the Templars, a payment to the patrons was made by the head of Richerenches, and the first of these transactions took place in the house of Richerenches ${ }^{39}$; and most of the brothers mentioned in documents relating to Roaix were usually resident at Richerenches. Roaix seems therefore to have still been dependent on Richerenches, although it was clearly different from some other dependencies and was at a rather later stage of development. 
The function of Templar houses in the West was partly to provide resources and recruits for the Holy Land, and as the Order expanded it became necessary to have an intermediate authority between houses in western Europe and the Order's headquarters in the East in order to co-ordinate the supplying of the Holy Land as well as to provide supervision over Templar foundations. The Hospital had already begun to establish priories - that of St Gilles was in existence by $1123-{ }^{40}$, and the Temple followed suit by creating provinces. The first indication of the grouping of Templar possessions in Catalonia and districts to the north of the Pyrenees is provided by the career of Hugh Rigaud, who between 1128 and 1136 was mentioned in documents drawn up in Catalonia and in some districts to the north of the Pyrenees: when the Templars first came to these areas Raymond Berenguer III was, of course, both ruler of Catalonia and count of Provence. Hugh Rigaud was called procurator on one occasion, but he was usually given no other title ${ }^{41}$. He was succeeded by the Catalan Arnold of Bedós. He has sometimes been identified as the head of the house of Richerenches ${ }^{42}$, but he had wider responsibilities. In a Catalan document of 1136 he was described as "nostre terre prior" ${ }^{43}$, and in the period up to 1139 he was frequently named in documents copied into the cartularies of Douzens, Masdéu and Richerenches as well as in Catalan sources: he was occasionally given the title of magister ${ }^{44}$, though without any territorial qualification. Neither of these Templars was named in documents relating to Aragon and Navarre, but Peter of Rovira, who succeeded Arnold of Bedós, was active in these kingdoms. Raymond Berenguer IV had acquired lordship over Aragon in 1137, while Navarre had been under Aragonese rule until 1134.45. Peter of Rovira also exercised authority in some adjacent territories under Castilian rule. In 1146 he was given property near Soria by Alfonso VII, and a number of documents relating to districts under Castilian rule were copied into the $12^{\text {th }}$ century cartulary of the Aragonese house of Novillas ${ }^{46}$. Peter of Rovira was not only called magister in a number of documents ${ }^{47}$ : in 1143 , he was said to be master in Provence and a certain part of Spain $^{48}$ - a title which became the norm until Provence became a separate province in the 13th century.

11 At no time was Templar administration at the provincial level very elaborate. It became the accepted practice, however, to hold an annual provincial chapter. The Hospital was holding prioral chapters as early as $1123^{49}$, but it is not clear when the Templars' first provincial assembly was held. A chapter at Arles was mentioned in a document of 1142 . Peter of Rovira was named, as were three other Templars who were apparently from Catalonia and Douzens, while many others were said to be present ${ }^{50}$. This assembly could have been a provincial chapter, but the evidence is insufficient to be certain. An agreement reached with the bishop of Roda during the siege of Lleida in 1149 was apparently also confirmed in a Templar chapter, but the wording of the surviving document is lacking precision ${ }^{51}$. Nevertheless, although the surviving sources are not always very helpful, it is clear that by 1150 a number of convents had been established in north-eastern Spain and in lands beyond the Pyrenees, and that a province of the Order had been created which straddled the Pyrenees. 


\section{BIBLIOGRAPHY}

Primary Sources

Manuscripts

Madrid, Archivo Histórico Nacional, Códice 595B/691.

Printed Sources

Cartas de población del reino de Aragón en los siglos medievales. Ed. María L. Ledesma Rubio. Zaragoza: Institución Fernando el Católico, 1991.

Cartulaire de la commanderie de Richerenches de l'ordre du Temple (1136-1214). Ed. Marquis de Ripert-Monclar. Avignon-Paris: Seguin/Champion, 1907.

Cartulaire général de l'ordre du Temple, 1119?-1150. Ed. Marquis d'Albon. Paris: Champion, 1913.

Cartulaires des Hospitaliers et des Templiers en Dauphiné. Ed. C.-U.-J. Chevalier. Vienne: E. J. Savigné, 1875.

Cartulaires des Templiers de Douzens. Ed. Pierre Gérard and Elisabeth Magnou. Paris: Bibliothèque Nationale, 1965.

Collecció diplomàtica de la casa del Temple de Barberà (945-1212). Ed. Josep M. Sans i Travé. Barcelona: Generalitat de Catalunya, 1997.

Collecció diplomàtica de la casa del Temple de Gardeny (1070-1200). Ed. Ramon Sarobe i Huesca. 2 vols. Barcelona: Fundació Noguera, 1998.

“Colección diplomática de Grisén (siglos XII y XIII)”. Ed. María L. Ledesma Rubio. Estudios de edad media de la Corona de Aragón 10 (1975), pp. 691-820.

Colección diplomática medieval de la Rioja. Ed. Ildefonso Rodríguez de Lama. 4 vols. Logroño: Instituto de Estudios Riojanos, 1976-1989.

Diplomatari del Masdéu. Ed. Rodrigue Tréton. 5 vols. Barcelona: Fundació Noguera, 2010.

“Documentos para el estudio de la reconquista y repoblación del valle del Ebro". Ed. José M. Lacarra. Estudios de edad media de la Corona de Aragón 5 (1952), pp. 511-668.

Les Gesta Comitum Barchinonensium (versió primitiva), la Brevis Historia i altres textos de Ripoll. Ed. Stefano M. Cingolani. Valencia: Universitat de Valencia, 2012.

Gesta Comitum Barcinonensium. Ed. Louis Barrau y Dihigo and Jaime Massó Torrents. Barcelona: Casa de caritat, 1925.

Liber Feudorum Maior. Ed. Francisco Miquel Rosell. 2 vols. Barcelona: Consejo Superior de Investigaciones Científicas, 1945-1947.

Papsturkunden für Templer und Johanniter. Ed. Rudolf Hiestand. Göttingen: Vandenhoeck and Ruprecht, 1972.

Els pergamins de l'Arxiu Comtal de Barcelona, de Ramon Berenguer II a Ramon Berenguer IV. Ed. Ignasi J. Baiges, Gaspar Feliu, Josep M. Salrach et al. 4 vols. Barcelona: Fundació Noguera, 2010.

Procès des Templiers. Ed. Jules Michelet. 2 vols. Paris: Imprimerie Royale, 1841-1851.

Els testaments dels comtes de Barcelona i dels reis de la Corona d'Aragó. De Guifré a Joan II. Ed. Antoni Udina i Abelló. Barcelona: Fundació Noguera, 2001. 
Studies

CARRAZ, Damien - L'ordre du Temple dans la basse vallée du Rhône (1124-1312). Ordres militaires, croisades et sociétés méridionales. Lyon: Presses Universitaires de Lyon, 2005.

DEMURGER, Alain - "L'implantation des Templiers en France au milieu du XII siècle". in SANS I TRAVÉ, Josep M.; SERRANO DAURA, Josep (ed.) - Actes de les jornades internacionals d'estudi sobre els orígens i l'expansió de l'orde del Temple a la Corona d'Aragó (1120-1200). Tarragona: Diputació de Tarragona, 2010, pp. 151-164.

FREEDMAN, Paul H. - "Els Templers al castell de Granyena segons un document de l'Arxiu Episcopal de Vic”. Ausa 11 (1983), pp. 1-5.

LAPEÑA, Ana I. - "La encomienda de la orden del Temple en Novillas (siglo XII)". Cuadernos de estudios borjanos 3 (1979), pp. 95-172.

LEMA PUEYO, José A. - "Las cofradías y la introducción del Temple en los reinos de Aragón y Pamplona: guerra, intereses y piedad religiosa". Anuario de estudios medievales 28 (1998), pp. 311-331.

LÉONARD, Émile G. - Introduction au cartulaire manuscrit du Temple (1150-1317) constitué par le Marquis d'Albon. Paris: Champion, 1930.

LUTTRELL, Anthony - "Los orígenes de la encomienda templaria en el Occidente latino". in SANS I TRAVÉ, Josep M.; SERRANO DAURA, Josep (ed.) - Actes de les jornades internacionals d'estudi sobre els orígens i l'expansió de l'orde del Temple a la Corona d'Aragó (1120-1200). Tarragona: Diputació de Tarragona, 2010, pp. 55-68.

MARTÍNEZ DIEZ, Gonzalo - Los Templarios en la Corona de Castilla. Burgos: La Olmeda, 1993.

MIGNON, Jean-Marc; CARRAZ, Damien - "La maison templière de Richerenches (Vaucluse). Premiers résultats de l'étude archéologique et architecturale”. Archéologie du Midi médiéval 26 (2008), pp. 131-143.

RILEY-SMITH, Jonathan - "The Origins of the Commandery in the Temple and the Hospital". in LUTTRELL, Anthony; PRESSOUYRE, Léon (ed.) - La commanderie. Institution des ordres militaires dans l'Occident médiéval. Paris: Comité des travaux historiques et scientifiques, 2002, pp. 9-18.

RILEY-SMITH, Jonathan - The Knights Hospitaller in the Levant, c. 1070-1309. Basingstoke: Palgrave Macmillan, 2012.

SELWOOD, Dominic - The Knights of the Cloister. Templars and Hospitallers in Central-Southern Occitania 1100-1300. Woodbridge: Boydell Press, 1999.

UBIETO ARTETA, Agustín - "Cofrades aragoneses y navarros de la milicia del Temple (siglo XII)". Aragón en la edad media 3 (1980), pp. 29-93.

VILAGINÉS I SEGURA, Jaume - "Pere de Rovira, un templer del Vallès". Notes (Centre d'estudis molletans) 20 (2005), pp. 43-61.

\section{NOTES}

1. The following abbreviations are used: $C D=$ Cartulaires des Templiers de Douzens. Ed. Pierre Gérard and Elisabeth Magnou. Paris: Bibliothèque Nationale, 1965; CHTD = Cartulaires des Hospitaliers et des Templiers en Dauphiné. Ed. C.-U.-J. Chevalier. Vienne: E. J. Savigné, 1875; CR = Cartulaire de la commanderie de Richerenches de l'ordre du Temple (1136-1214). Ed. Marquis de Ripert-Monclar. Avignon-Paris: Seguin/Champion, 1907; CT = Cartulaire général de l'ordre du Temple, 1119?-1150. Ed. 
Marquis d'Albon. Paris: Champion, 1913; DM = Diplomatari del Masdéu. Ed. Rodrigue Tréton. 5 vols. Barcelona: Fundació Noguera, 2010.

2. CT, pp. $45-47,66$ docs. $63,87$.

3. CT, pp. 25, 36-37, 53 docs. 33, 47, 70; Collecció diplomàtica de la casa del Temple de Barberà (945-1212). Ed. Josep M. Sans i Travé. Barcelona: Generalitat de Catalunya, 1997, pp. 102-104, docs. 27-28; Els pergamins de l'Arxiu Comtal de Barcelona, de Ramon Berenguer II a Ramon Berenguer IV. Ed. Ignasi J. Baiges, Gaspar Feliu, Josep M. Salrach et al. 4 vols. Barcelona: Fundació Noguera, 2010, 3, pp. 1091-1093, 1096-1097, docs. 652, 655.

4. CT, p. 55 doc. 72; Pergamins de l'Arxiu Comtal..., 3, pp. 1120-1123, doc. 671; Collecció diplomàtica de la casa del Temple de Gardeny (1070-1200). Ed. Ramon Sarobe i Huesca. 2 vols. Barcelona: Fundació Noguera, 1998, 1, pp. 84-87, doc. 6.

5. RILEY-SMITH, Jonathan - "The Origins of the Commandery in the Temple and the Hospital". in LUTTRELL, Anthony; PRESSOUYRE, Léon (Ed.) - La commanderie. Institution des ordres militaires dans l'Occident médiéval. Paris: Comité des travaux historiques et scientifiques, 2002, p. 10.

6. CT, p. 279 , doc. 447.

7. Collecció diplomàtica de la casa de Gardeny ..., 1, pp. 115-116, doc. 26. A document dated in the 26th year of Louis which refers to the "milicia de Garden" has been assigned to the year 1134: CT, p. 63, doc. 82; Pergamins de l'Arxiu Comtal ..., 3, pp. 1129-1131, doc. 677. But as the nearby city of Lleida was not captured by Raymond Berenguer IV until 1149, the document must be referring to Louis VII: in Collecció diplomàtica de la casa de Gardeny ..., 1, pp. 230-231, doc. 119, it is more properly assigned to the year 1163. Albon also published a document recording a grant in 1134 by Ramiro of Aragon to the cavaleatores of Zaragoza, but there is no reason to assume that these were Templars: CT, p. 68, doc. 91; "Documentos para el estudio de la reconquista y repoblación del valle del Ebro". Ed. José M. Lacarra. Estudios de edad media de la Corona de Aragón 5 (1952), pp. 556-557, doc. 334; "Colección diplomática de Grisén (siglos XII y XIII)". Ed. María L. Ledesma Rubio. Estudios de edad media de la Corona de Aragón 10 (1975), p. 700, doc. 1.

8. CT, pp. 183-186, doc. 281.

9. CT, p. 119 , doc. $171 ; D M, 2$, pp. 376-378, doc. 19.

10. $C T$, pp. 131-132, pp. 155-156, docs. 190,230 ; $C R$, pp. 17, pp. 88-91, docs. 13, 89; see also $C T$, p. 194, doc. 297 , and $C R$, pp. 22-23, doc. 19, for a later document which refers to the house of Richerenches "que edificatur, ad edificacionem et sustentationem milicie que est in Templo Ierosolimitani constituta"; cf. CT, p. 80, doc. 113; DEMURGER, Alain - "L'implantation des Templiers en France au milieu du XII ${ }^{e}$ siècle". in SANS I TRAVÉ, Josep M.; SERRANO DAURA, Josep (Ed.) - Actes de les jornades internacionals d'estudi sobre els orígens i l'expansió de l'orde del Temple a la Corona d'Aragó (1120-1200). Tarragona: Diputació de Tarragona, 2010, p. 160.

11. MIGNON, Jean-Marc; CARRAZ, Damien - "La maison templière de Richerenches (Vaucluse). Premiers résultats de l'étude archéologique et architecturale”. Archéologie du Midi médiéval, 26 (2008), pp. 131-143.

12. CARRAZ, Damien - L'ordre du Temple dans la basse vallée du Rhône (1124-1312). Ordres militaires, croisades et sociétés méridionales. Lyon: Presses Universitaires de Lyon, 2005, p. 92.

13. CT, p. 122, doc. 177; "Documentos para el estudio...", pp. 564-565, doc. 342 (where the date is discussed).

14. CT, pp. 140-141, doc. 202; Pergamins de l'Arxiu Comtal..., 3, pp. 1257-1258, doc. 763.

15. $C T$, pp. $120-121$, pp. $271-272$, p. 289 , docs $174,435,464$; $C R$, pp. $49-50$, doc. 48 ; $C D$, pp. 45 , pp. 180-181, docs. A 34, 207.

16. CT, pp. 78,235 , docs. 109,367 . The second document is dated 1145 , but it was said to have been issued in the year when Raymond Berenguer IV gave Monzón to the Templars (1143). 
17. $C T$, pp. $129-130$, p. 159 , p. 182 , docs. $189,235,278$; $C R$, pp. $5-7$, p. 40 , pp. $161-162$, docs. 3,37 , 185. A document dated July 1147 in a Douzens cartulary similarly names ten brothers: $C T$, pp. 287-288, doc. 462; CD, pp. 275-277, doc. D 4.

18. $C T$, pp. $155-156$, p. 159 , pp. $182-183$, p. 260 , p. 350 , p. 367 , docs. 230 , 235, 278-279, 413, 565, 596; CR, p. 17 , pp. $30-31$, p. 40 , p. 51 , pp. $54-55$, pp. $68-69$, p. 141 , p. $161-162$, docs. $13,29,37,50,53,66$, 157, 185.

19. $C D$, pp. $9-12$, doc. A 4 .

20. CT, pp. 87 , pp. 106-107, pp. 112-113, docs. 125 , 152, 161; CR, pp. 4-5, pp. 29-30, pp. 36-37, docs. 2, 28, 33; CARRAZ, Damien - L'ordre du Temple ..., p. 92. A chaplain mentioned in 1140 may have then been residing at Palau: $C T$, pp. 140-141, doc. 202.

21. FREEDMAN, Paul H. - "Els Templers al castell de Granyena segons un document de l'Arxiu Episcopal de Vic". Ausa 11 (1983), p. 4.

22. FREEDMAN, Paul H. - "Els Templers al castell de Granyena (...)", p. 3.

23. FOREY, Alan J. - The Templars in the Corona de Aragón. London: Oxford University Press, 1973, p. 431.

24. DM, 5, p. 2904; Procès des Templiers. Ed. Jules Michelet. 2 vols. Paris: Imprimerie Royale, 1841-1851, 2, p. 454; see also below, note 38. The right to have brother chaplains granted by Innocent II in 1139 was clearly confirming an existing practice: Papsturkunden für Templer und Johanniter. Ed. Rudolf Hiestand. Göttingen: Vandenhoeck and Ruprecht, 1972, pp. 204-210, doc. 3.

25. CT, p. 12, doc. 18; CD, p. 269, doc. C 11; SELWOOD, Dominic - The Knights of the Cloister. Templars and Hospitallers in Central-Southern Occitania 1100-1300. Woodbridge: Boydell Press, 1999, pp. 61-62, 64.

26. CT, p. 88, doc. 127; Pergamins de l'Arxiu Comtal..., 3, pp. 1176-1177, doc. 711.

27. $C T$, pp. 51-52, doc. 68: DM, 2, pp. 363-365, doc. 10.

28. CT, p. 97, doc. 139; DM, 2, pp. 368-370, doc. 14; see also Pergamins de l'Arxiu Comtal..., 3, pp. 1422-1423, doc. 881.

29. LUTTRELL, Anthony - "Los orígenes de la encomienda templaria en el Occidente latino" ..., p. 57 , argues that the obligation to bury confratres did not necessarily imply burial at a Templar house: it might take place at a parochial church which did not belong to the Order. But the document quoted in support merely states that in 1133/1134 the bishop of Soissons promised free burial of Templars at a time when they were only beginning to establish bases in the West: CT, pp. 42-43, doc. 59; and it is difficult to understand why, if burial were to be at a parish church, an obligation should be placed on the Templars.

30. Madrid, Archivo Histórico Nacional, Códice 595B/691, fols. 166-182, docs. 421-422; published in UBIETO ARTETA, Agustín - "Cofrades aragoneses y navarros de la milicia del Temple (siglo XII)". Aragón en la edad media 3 (1980), pp. 53-64; the dating is discussed on pp. 33-34. The dating is also examined by LAPEÑA, Ana I. - "La encomienda de la orden del Temple en Novillas (siglo XII)". Cuadernos de estudios borjanos 3 (1979), p. 117. For further discussion of these confaternities see LEMA PUEYO, José A. - "Las cofradías y la introducción del Temple en los reinos de Aragón y Pamplona: guerra, intereses y piedad religiosa”. Anuario de estudios medievales 28 (1998), pp. 311-331. The lists record only the donations made by confratres, and do not mention burial, but the interment of confratres by the Temple became the normal practice.

31. Ambel lies to the south of Novillas.

32. Cartas de población del reino de Aragón en los siglos medievales. Ed. María L. Ledesma Rubio. Zaragoza: Institución Fernando el Católico, 1991, pp. 94-95, doc. 70; CT, p. 333, doc. 543.

33. CT, p. 368, doc. 597; Pergamins de l'Arxiu Comtal..., 3, pp. 1462-1463, doc. 908.

34. Gesta Comitum Barcinonensium. Ed. Louis Barrau y Dihigo and Jaime Massó Torrents. Barcelona: Casa de caritat, 1925, p. 38. 
35. Gesta comitum Barcinonensium, p. 8; Les Gesta Comitum Barchinonensium (versió primitiva), la Brevis Historia i altres textos de Ripoll. Ed. Stefano M. Cingolani. Valencia: Universitat de Valencia, 2012, p. 133.

36. Liber Feudorum Maior. Ed. Francisco Miquel Rosell. 2 vols. Barcelona: Consejo Superior de Investigaciones Científicas, 1945-1947, 1, pp. 527-532, doc. 493; Els testaments dels comtes de Barcelona i dels reis de la Corona d'Aragó. De Guifré a Joan II. Ed. Antoni Udina i Abelló. Barcelona: Fundació Noguera, 2001, pp. 97-103; Pergamins de l'Arxiu Comtal..., 3, pp. 1058-1065, doc. 633.

37. CT, pp. 160-161, p. 324, p. 360, docs. 238, 527, 586; CHTD, pp. 68, pp. 71-73, docs. 110, 115.

38. CT, p. 324 , doc. 527 ; CHTD, p. 68 , doc. 110. In $1138 / 1139$ the bishop of Vaison had granted the Templars the right to build a church "ubicumque eis placuerit in predicto territorio de Roaisso", and the gift included the right to have a cemetery and oblations and all other ecclesiastical rights: the wording does not suggest that he was referring to a Templar chapel: $C T$, pp. 125-126, doc. 182; CHTD, pp. 62-64, doc. 104. A document drawn up in 1150 which mentions tithes of the church of St. Mary in Roaix was also not referring to a Templar chapel: CT, p. 324, doc. 527; CHTD, p. 68, doc. 110. In 1141 the bishop of Vaison had further referred to the house of Roaix "que in nostro episcopatu gratia Dei est et hedificatur"; yet the wording is not as explicit as that in the documents relating to the construction of houses at Masdéu and Richerenches: CT, pp. 160-161, doc. 238; CHTD, pp. 71-73, doc. 115.

39. $C T$, p. 324 , p. 360 , docs. 527, 586; CHTD, p. 68, doc. 110.

40. RILEY-SMITH, Jonathan - The Knights Hospitaller in the Levant, c. 1070-1309. Basingstoke: Palgrave Macmillan, 2012, p. 188 and p. 194.

41. $C T$, p. 45 , doc. 62. A brother Hugh is mentioned as magister in 1136 in a Catalan document, and this has been taken to refer to Hugh Rigaud: FREEDMAN, Paul H. - "Els Templers al castell de Granyena (...)"..., pp. 3-4; but it seems more likely that the Templar in question was the master of the Order, Hugh of Payns.

42. CR, p. cliv; LÉONARD, Émile G. - Introduction au cartulaire manuscrit du Temple (1150-1317) constitué par le Marquis d'Albon. Paris: Champion, 1930, p. 40; CARRAZ, Damien - L'ordre du Temple..., p. 91.

43. FREEDMAN, Paul H. - "Els Templers al castell de Granyena (...)"..., p. 4.

44. CT, pp. 84-85, p. 101, docs. 121, 144; CR, pp. 48-49, doc. 47; Pergamins de l'Arxiu Comtal..., 3, pp. 1197-1199, doc. 727.

45. On Peter of Rovira's background, see VILAGINÉS I SEGURA, Jaume - "Pere de Rovira, un templer del Vallès". Notes (Centre d'estudis molletans) 20 (2005), pp. 43-61.

46. CT, pp. 257-258, doc. 410; Archivo Histórico Nacional, Códice 595B/691, fols. 153, 154v-157v, 159, docs. 390, 392-397, 402; Colección diplomática medieval de la Rioja. Ed. Ildefonso Rodríguez de Lama. 4 vols. Logroño: Instituto de Estudios Riojanos, 1976-1989, 2, pp. 218-219, pp. 242-243, pp. 257-258, p. 260, pp. 262-263, pp. 268-269, p.278, docs. 146, 169, 183, 185, 187, 192, 200; “Documentos para el estudio (...)” ..., pp. 582-583, pp. 593-595, docs. 363, 377-379.

47. See, for example, $C T$, pp. 140-141, p. 158, p. 163, p. 166, docs. 202, 233, 242, 246; DM, 2, pp. 381-382, pp. 385-386, docs. 22, 25; CD, pp. 23-24, doc. A 11. No provincial master in Castile or León is known until the later 1170s: MARTÍNEZ DIEZ, Gonzalo - Los Templarios en la Corona de Castilla. Burgos: La Olmeda, 1993, p. 63 and p. 66.

48. CT, pp. 204-205, doc. 314; Pergamins de l'Arxiu Comtal ..., 3, pp. 1334-1339, doc. 822; Collecció diplomàtica la casa de Barberà..., pp. 110-114, doc. 35; Collecció diplomàtica de la casa de Gardeny ..., 1, pp. 89-93, doc. 9.

49. RILEY-SMITH, Jonathan - Knights Hospitaller ..., p. 194.

50. CT, pp. 183-186, doc. 281.

51. CT, pp. 345-346, doc. 557.

Medievalista, 30 | 2021 


\section{ABSTRACTS}

Information about the creation of Templar convents and a province in Provence, north-eastern Spain and neighbouring territories before 1150 is limited. Some types of evidence, however, suggest the establishment of convents. These include references to the construction of buildings to house Templars; the introduction of the term magister to describe some local officials; lists of brothers resident in a particular place; the appearance of the offices of claviger ("keeper of the keys") and chaplain; and the close links formed between some laymen and Templar communities. It is clear that some convents were also setting up dependencies or granges by the middle of the 12th century. From very early on, there was a Templar official with authority on both sides of the Pyrenees, and he came to be given the title of magister, although the first reference to the province of "Provence and a certain part of Spain" does not occur until 1143. It is possible, though not certain, that provincial chapters began to be convened before 1150 .

A informação sobre a criação dos conventos dos templários e da própria província da Provença, que incluía o nordeste de Espanha e territórios vizinhos antes de 1150, é limitada. Todavia, algumas provas sugerem a criação de conventos. Estas incluem referências à construção de edifícios para a habitação dos templários; a introdução do termo magister para descrever alguns oficiais locais; listas de freires residentes em determinado local; o aparecimento dos postos de claviger (claveiro, ou celeireiro) e de capelão; e os laços estreitos formados entre alguns leigos e as comunidades templárias. É claro que alguns conventos estavam também a estabelecer dependências ou granjas em meados do século XII. Havia desde muito cedo um oficial templário com autoridade em ambos os lados dos Pirenéus, a quem veio a ser dado o título de magister, embora a primeira referência à província de "Provença e uma certa parte de Espanha" não ocorra até 1143. É possível, embora não certo, que os capítulos provinciais tenham começado a ser organizados antes de 1150.

\section{INDEX}

Keywords: Templars, Convents, Province, Dependencies, Chapters

Palavras-chave: Templários, Conventos, Província, Dependências, Capítulos

\section{AUTHOR}

\section{ALAN FOREY}

Emeritus, University of Durham. The Bell House, Church Lane, Kirtlington, Oxon, OX5 3HJ, Oxford, United Kindgdom. alan.forey@mybroadbandmail.com 